\title{
OREOCHROMIS NILOTICUS AND OFFSPRINGS OF RED TILAPIA IN EGYPT: GENETIC PROSPECTIVE.
}

\section{Ezzat Awwad Badawy}

National Institute of Oceanography and Fisheries, Genetic Lab; Barrage Research Station; Kalyobia Governorate, Egypt.

Keywords: Oreohcromis niloticus, tilapia, genetic prospective .

(Received: May 25,1998).

\section{ABSTRACT}

B lood sera were collected from four Orechromis strains, NA from lake Nser, NK from the river Nile Knater area, NH1 (the near offspring of self spawned red tilapia) and $\mathrm{NH}$ (the far offspring of self spawning of NH1) both the fish farms around lake Qanun, El-Fayum Government. The electrophoretical analysis of their sera showed that the strain NA has the highest relative genetic purity followed NK and NH1, but NH2 is the lowest one.

\section{INTRODUCTION}

In Egypt, tilapia species constitute the major component of fish production either in fresh or brackish water or fish farms and cages (Badawy, 1993 \& Hussein, 1995). Tilapia species were mainly produced from the natural fisheris (lakes and River Nile and its branches and drains) as well as some Governmental and private fish farms (which are established beside or inside the lakes) until the first half of 1980s. During that time, each natural water body (lakes and river) had produced their own Tilapia species without transporting them from any water body to another except to the fish farms and no Tilapia species were imported from outside the country. Through the 1980 s decade large fish farms (Governmental, or private) were constructed with direct or indirect connection with the natural water bodies. Also, cages -for farming- fishes were istalled in many areas especially in the River Nile (Damietta branch) (Badawy, 1984\&1993). Trend has caused a considerable shortage in Tilapia seed supplies required for operating the new farms and cages. Therefore, Governmental hatcheries were established to overcome this problem. Some of these hatcheries produce the seeds of Oreochromis niloticus \& 0 . aureus, monosex tilapia hybrids (O. niloticus $\mathrm{X} O$. Aureus) of high male ratio (El-Atreby et al., 
1 992 \& Badawy. 1993). Othet hatcheries had impor irans of red Tilapia which are originally a mutant strain of (). mossambicus that (V.Itwil lower growth rate than () niloticus and $O$. Aureus Kwo, 1988). Offsprings of red (Il.tpta (which were produced under recurrent self spawning) and the monosex of the local ipecies were transported to the different fish farms and cages without control. They i waped to the neighboring natural water bodies (Lakes: Manzalla, Borullus, Edku, Qarun .mid Wadi El-Rayan and the River Nile and its branches and drains in the lower Egypt) where by crossbreeding caused genetic contamination with the local Oreochrom species which resulted in misidentifications of them (Badawy, 1993 and Badawy \& R $12 k a l l a, 1996)$

As for Lake Nasser in Aswan Governorate Egypt, it was believed that Oreochromis niloticus, Sarotherodon galilaeus and tilap.. sillii are the only tilapia species present in Lake Nasser (Payne \& Collinson, 1983 and man others). But during 1996, when the present writer together with some fellows were in the "esearch Centre of the Authority of Lake Nasser Development Authority beside Lake Nasier for selecting and spawning a broad stock of $O$. niloticus. seined from the Lake. fishes of $O$. aureus were then collected among the seine that was considered mainly is $O$. niloticus, in addition to $S$. galilaeus and Tilapia zilli. This case was so astonishint to the working in that area. So, Lake Nasser is considered as the only place which is not unvaded by the hybrid Tilapia and consequently indicating no genetic contamination.

On the other hand, in spite of the discovery of the presence of $O$. aureus in the Lake, their crossing with $O$. niloticus is extremely rare. Thus is because (in addition to their very low ratio) in the natural conditions in the nature. each species reproduce intemally (inbreeding or self spawning) and the crossbreeding occurs only under unnatural conditions (Mires, 1982 \& Badawy, 1993). Therefore, $O$. niloticus exhibits the highest relative genetic purity in Egypt. Thus, the aim of this study is to make genetic comparison between $O$. niloticus -from Lake Nasser- and the hybrid generations of red tilapia that is widely expanded in the fish farms in El-Fayum Governorate and escaped to Lake Qarun and Wadi El-Rayan.

\section{MATERIAL AND METHODS}

During operating the private fish farms around Lake Qarun, El-Fayum Governorate (1996), two Oreochromis strains -similar to O. niloticus-were found in the 
farms. The $1^{*}$ strain, which was silvery bright in appearance, was originally brought from a hatchery in Alexandria Govemarate (as mentioned by the farms) and later was known to be the nearby offspring of self spawning of red Tilapia. But the $2^{\text {of }}$ strain was known to be the far offspring of recurrent self spawning of the offspring of red Tilapia in a private hatchery near Lake Qarun.

Sera were collected from the blood of four Oreochromis strains: 1)O. niloticus (NA) from Lake Nasser (collected during selecting and spawning $O$. niloticus the Japanese hatchery near Lake Nasser, 1996), 2) O. niloticus (NK) From the River Nile (at Kanater City region, Kalyobia Governarate), $3 \& 4) 1^{*}$ and $2^{\text {nd }}$ Oreochromis hybrid strains (NHI) and (NH2), both from El-Fayum fish farms as previously mentioned. After sera collection, they were iced, sent to the Barrage Research Station and kept under $-30^{\circ} \mathrm{C}$. The sera were fractionated on disc electrophresis using 7.5 acrylamide (Herzberg and pasteur, 1975). After running, the gels were stained in Amidoblkack 10B for 30-60 minutes, destasined and stored in $7 \%$ acetic acid. The gels were scanned using densitometer. The change in genelic characters of each strain was represented by the polymorphism in the serum proteinogram fractions depending on their frequency of appearance (Payne er al., 1971 \& Wilkins, 1971. The similarity between the strain pairs of electrophorotic patterns can be calculated (Ferguson, 1980) from the equation:

No. of bands of common mobility

Similarity coefficient $=$

Maximum No. of band in an individual

High SC between pairs means high genetic similarity and vice versa. The height and area of the peak indicate the fraction's intensity and thickness, respectively.

\section{RESULTS}

The results presented in Table (2) show that the eloctrophoretic senum proteinogram of the Oreochromis (NA) -from Lake Nasser- has revealed polymorphism in the fractions number $5,6 \& 9$ (frequency of appearance among individuals $: 86.7,86.7$ \& $73.3 \%$ ). But NK strain, from the River Nile, (Kanater area) showed polymorphism in 5 fractions (No. $3,4,6,8 \& 14$, their appearance $\%$ is $83.3,83.3,33.3,75.0 \& 58.3 \%$, respectively). While the polymorphic fractions, numbers $2.3,8 \& 9$ (appearance $\%: 70.0$, 
$70.0,80.0 \& 80,0 \%$ ) and those number $2,3,6 \& 7$ (app. \%: $70.0,80.0,70.0 \& 70.0 \%$ ) were recorded in the electrophorogram of the two strains $\mathrm{NH} 1$ and $\mathrm{NH} 2$, respectively. While the fractions $13 \& 15$ disappeared completely from $N H 2$ strain (Tables $1 \& 2$ ).

The genetic similarity between the members of the 4 strains appears from the values of the similarity coefficients $(\mathrm{SC})$ of the mobility of their nonsignificant fractions (Table 3). The NA strain showed SC of $0.67,0.60$ and 0.53 with the strains NK, NHI \& NH2, respectively. While SC of $0.60,0.40 \& 0.53$ were between $N K$ and both of NH1 \& $\mathrm{NH} 2$ and between $\mathrm{NH1} \& \mathrm{NH} 2$, respectively.

The quantitative statistical analysis between areas under peaks (Fraction's intensity and thickness)for the fractions of different strains in their sera electrophorograms revealed that NA X NH2 (9 fractions), NA X NH1 (8 fractions), NK X Nhl (8 fractions), NA X NK (6 fractions) and the lowest number was beNK X NH2 (5 fractions).

\section{DISCUSION}

Oreochromis niloticus exhibits the highest growth rate among Tilapia species (Wohlfarth \& Hulata, 1981 and Badawy, 1993). Also, the female O. niloticus produces 9 hybrids (of high male percentage, may reach $100 \%$ males). The male ratios, in these hybrids, depend on the degree of genetic purity of the parents (Mires, 1982; Badawy 1993 \& Badawy \& Rizkalla, 1996).

In the present study, the four Oreochromis strains, NA, NK, NH1 \& NH2 showed polymorphism in 3 fractions (No. 5, $6 \& 9$ ) and 4 fractions (No.: 2, 3, $6 \& 7$ ), respectively. This polymorphism is of genetic character. Chen and Tstryuki (1970) declared that transferrin (Beta-globulin represents the major fractions in the senum of tilapia) showed marked produced polymorphism and genetically controlled by different alleles. Wajdani (1970) mentioned that in Sarotherodon niloticus and S. aureus (now Oreochromis) and their hybrids, there are 5 bands (fractions) from number 5 to number 9 that are restricted to transferrin.

The genetic similarities (similarity coefficients, SC)exhibited by NA with NK, NH1 \& NH2 were $0.67,0.60 \& 0.53$ and significance in the relative area in 6,8 \& 10 fractions, respectively. This indicates that the NA strain from Lake Nasser has the highest relative genetic purity followed by NK strain from the Nile (Kanater area) and the NH1 
strain (the near offspring of red tilapia). But the NH2 strain (the far offspring by recurrent self spawning of red tilapia) showed the lowest rclative genetic purity.

On comparing the fractions of NKxNH1, NKxNH2 and NH1xNH2 they showed $\mathrm{SC}$ of $0.60,0.40 \& 0.53$ with significance in $8,5 \& 9$ fractions in the relative area. This substantiate that NA strain is the most genetically pure strain followed by NK and NHl and $\mathrm{NH} 2$ strain is the lowest one. These results are in agreement with the present status of Oreochromis niloticus in the different Egyptian water bodies as previously mentioned in the chapter of introduction.

On the other hand, it was noticed that the SC between the different strains ranged between 0.40 and 0.67 . This indicates that the genetic similarity between the 4 strains is low. This because the $\mathrm{NHI} \& \mathrm{NH} 2$ strains are generations of the selfspawning of red tilapia which was originally a red strain (caused by mutation in Taiwan) of Oreochromis mossambicus whose growth rate is low (Kuo, 1988). Therefore, spreading of the offspring of red tilapia in the majority of the natural water bodies caused crossing with the local Oreochromis strains that resulted in introgression of unwanted genetic characters causing genetic contamination. Similar results were recorded by Hulata et al. (1981) who found that the growth rate of the hybrid Sarotherodon niloticus X $S$. hornorum is faster than that $S$. mossambicus and S. hornorum

\section{REFFERENCES}

Badawy, E. A. (1984) : Experimental fresh water cage culture of some fishes in Egypt. M.Sc. Thesis Fac. Sc. Zagazig Univ., 121 P.

Badawy, E. A. (1993): Biological studies on tilapia species as a major component of the Egyptian farming system. Ph. D. Thesis, alities on the male ratio of their hybrids. Bull. Nat. Inst. Of Oceanogr. \& Fish., A. R. E., 22 : 255-266.

Chen, Y. F. \& Tsuyuki, H. (1970): Zone electrophoretic studies on the proteins of Tilapia hormurum and their F1 hybrids, Tilapia zillii and Tilapia melanopleura. J. Fish. Res. Bd. Can, 27 : 2167-2177.

El-Etreby, S. G.; Ghoneim, S. I; El-Alamy, MA and Abd El-Mawgoud, M (1992): Mono-sex production of Tilapia species. 1-hybridization between Oreachromis niloticus and Sarotherodon aureus J. Egypt. Ger. Soc. Zool., 8(B), 1-18.

Ferguson, A (1980):Biochemical systematic and evolution. Glasgo. Blackie 
Herzberg, A. and Pasteur, R. (1975): The identification of the grey mullet species by disc electrophoresis. Aquaculture, $5: 99-106$.

Hualta, G.; Rothbard, S. \& Wohlfarth, G. W. (1981) : Genetic approach to the production of all-male progeny of tilapia. Europian Mariculture Soc. Spec. Publ., $6: 181-190$

Hussein, M. S. (1995): Semi-intensive fish culture in some Egyptian fish farms. Ph D. Thesis, Fac. Agri. Suez Canal Univer. 256 PP.

Kuo, H. (1988): Progress in genetic improvement of red hybrid tilapia in Taiwan. P 219221. The Second International Symp. on Tilapia in Aquaculture. Proc.15 PP. 623.

Mires, D. (1982): Study of the problem of mass production of hybrid tilapia fry. P. 317-329. The biology and culture of Tilapias. ICLARM Conf., Proceedings 7. $432 \mathrm{pp}$.

Payne, A.I. \& Collinson, R. I. (1983): A comparison of biological characteristics of Sarotherodon niloticus (L.) with those of Sarotherodon aureus (Steindachner) and other tilapia of Delta and lower Nile. Aquaculture, $30: 335-351$.

Payne,R. H.; Child, A.R. \& Forrest, A. (1971): Geographical variation in the Atlantic salmon. Nature, $231: 250-252$.

Wilkins, N.P. (1971): Biochemical and serological studies on the Atlantic Salmon(Salmo Salar). Rapp. Reun, $161: 91-95$.

Wohlfarth,G.W. and Hulata, G. (1981): The applied genetics of Tilapia. ICLARM Studies and Review. 6, 26. P. Manilla, Philippines. 
Table (1): Means and slandard deviations of relative mobility and relative area percentage for individual serum protein fractions of the studied Oreochromis strains

\begin{tabular}{|c|c|c|c|c|c|c|c|c|c|}
\hline \multirow{2}{*}{\multicolumn{2}{|c|}{$\begin{array}{l}\text { Fraction } \\
\text { No. / Mean }\end{array}$}} & \multicolumn{4}{|c|}{ Realtive mobility } & \multicolumn{4}{|c|}{ Realtive area pecentage } \\
\hline & & IA & NK & $\mathbf{N H 1}$ & $\mathrm{NH} 2$ & $\mathbf{N A}$ & NK & $\mathrm{NH1}$ & $\mathrm{NH2}$ \\
\hline \multirow[t]{2}{*}{7} & $x^{1}$ & 100 & 100 & 100 & 100 & 0.7 & 1.8 & & 7.8 \\
\hline & \pm & 00 & 0.00 & 0.00 & 0.00 & .06 & .54 & & $2.4 !$ \\
\hline \multirow[t]{2}{*}{2} & $x^{\prime}$ & 3.0 & 3.3 & 4.1 & 4.0 & 8.0 & 4.8 & & 3 \\
\hline & & & 74 & .05 & 1.24 & 2.35 & 2.35 & & .4 \\
\hline \multirow[t]{2}{*}{3} & $x^{\prime}$ & 3.8 & 7.5 & 0.1 & 9.6 & 3.8 & 3.8 & 3.6 & 2 \\
\hline & SD & & 77 & & & & & & 1.0 \\
\hline \multirow[t]{2}{*}{4} & & & 81.5 & 86.1 & 85.0 & 3.3 & 2.2 & 3.1 & \\
\hline & & & 1.38 & 3.45 & .22 & 1.80 & 1.04 & & \\
\hline \multirow[t]{2}{*}{5} & $x^{\prime}$ & $6 A$ & 76.2 & 81.5 & 78.4 & 25 & 25 & & \\
\hline & $\pm S D$ & 84 & 1.34 & 2.76 & 3.47 & 1.77 & 1.08 & & \\
\hline \multirow[t]{2}{*}{6} & $x^{\prime}$ & 1.4 & 71.8 & 74.5 & 72.5 & 2.1 & 2.5 & & \\
\hline & $\pm S D$ & 2.54 & 0.57 & 2.30 & 1.50 & 0.56 & 4.61 & 0.96 & 1.1 \\
\hline \multirow[t]{2}{*}{7} & $x^{\prime}$ & 65.9 & 68.2 & 62.2 & 65.9 & 3.0 & 6.3 & 34 & 6. \\
\hline & & 74 & 1.73 & 4.23 & 1.17 & 1.77 & 2.60 & 1.22 & 4.8 \\
\hline \multirow[t]{2}{*}{8} & $\bar{x}$ & 9.2 & 6.9 & 60.6 & 59.4 & 3.9 & 5.2 & 2.7 & \\
\hline & & & & & & & & & 9.0 \\
\hline \multirow[t]{2}{*}{9} & $x^{\prime}$ & & & & & & 8.1 & & \\
\hline & & & 1.97 & 1.78 & $3.39^{\circ}$ & 3.45 & 3.11 & & 0.1 \\
\hline \multirow[t]{2}{*}{10} & & & 48.7 & 50.5 & & 00 & 0. & & \\
\hline & +5 & & 1.75 & 2.36 & & 08 & 78 & & \\
\hline \multirow[t]{2}{*}{11} & $x^{\prime}$ & & 41.3 & 42.2 & 42.9 & 9.6 & 116 & & \\
\hline & $\pm S D$ & & 13 & 2.98 & 3.14 & 06 & 61 & 58 & 8.7 \\
\hline \multirow[t]{2}{*}{12} & $x^{\prime}$ & 39.1 & 38.0 & 39.4 & 36.1 & 10.3 & 15.0 & 13.9 & 12 \\
\hline & & 50 & 50 & 1.21 & 1.10 & 2.29 & 5.80 & & 6.3 \\
\hline \multirow[t]{2}{*}{13} & & & 3.8 & 34.9 & & 10.3 & 12.7 & & \\
\hline & $\pm S D$ & & 1.03 & 1.14 & 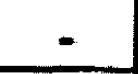 & 2.80 & 7.57 & 5.21 & - \\
\hline \multirow[t]{2}{*}{14} & & & 30.9 & 30.0 & 30.2 & & 8.9 & & 3. \\
\hline & en & & 0.99 & 1.65 & 1.10 & 4.40 & 3.91 & 3.30 & 0.9 \\
\hline \multirow[t]{2}{*}{15} & $x$ & & & 25 & - & 7.2 & 3.6 & & - \\
\hline & - & 2.25 & 1.20 & 1.95 & & 4.21 & 2.45 & 0.80 & \\
\hline
\end{tabular}


Table(2):Comparative ideratifeation mip, showing the frequency of appenrance of individut ereum

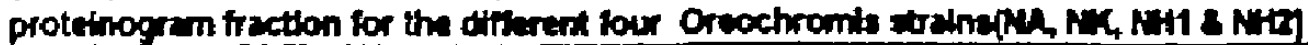

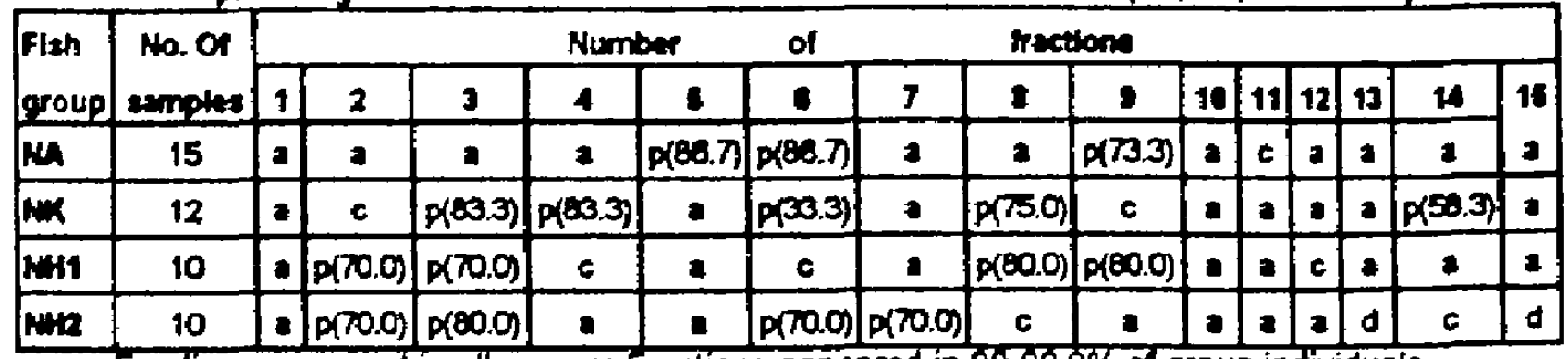

a: Fractions appeared in all gl c: fractions appeared in $90-99.9 \%$ o group indriduals

p: polymorphic appeared in lo d: Fractions disappeared completely from all group individuals

Table (3): Significant fractions in the mobility and relative area percentage in the serum proteinogram between the fourOreochromis strains

\begin{tabular}{|c|c|c|c|c|c|}
\hline \multirow{3}{*}{$\begin{array}{c}\text { Oreachrom } \\
\text { strains }\end{array}$} & & Mobility & \multirow[t]{3}{*}{ SCI } & \multirow{2}{*}{\multicolumn{2}{|c|}{$\frac{\text { Relative aera } \%}{\text { Significant fractions }}$}} \\
\hline & \multicolumn{2}{|c|}{ Significant fractions } & & & \\
\hline & No. & Fraction No. & & No. & Fraction No. \\
\hline NA $X$ & 5 & $7,9,11,12,13$ & 0.67 & $\theta$ & $2,4,6,7,12,15$ \\
\hline $\mathrm{NH1}$ & 6 & $2,3,4,5,6,10$ & 0.60 & 8 & $2,4,9, \uparrow 1,12,13,14,15$ \\
\hline $\mathrm{NH} 2$ & 5 & $2,3,4,10,12$ & 0.53 & 10 & $1,2,5,6,7,8,9,10,11,14$ \\
\hline NK $X$ & 6 & $2,3,4,5,6,10$ & 0.60 & 8 & $2,3,5,7,8,9,11,14$ \\
\hline NK $x$ & 7 & $3,4,5,7,9,10,12$ & 0.40 & 5 & $1,4,10,11,14$ \\
\hline $\mathrm{NH} 1 \times \quad \mathrm{NH} 2$ & 5 & $5,6,9,10,12$ & 0.53 & 9 & $1,2,3,5,7,8,8,10,14$ \\
\hline
\end{tabular}

$\mathrm{SC}$ : Similarity coefficient of fraction mobility 


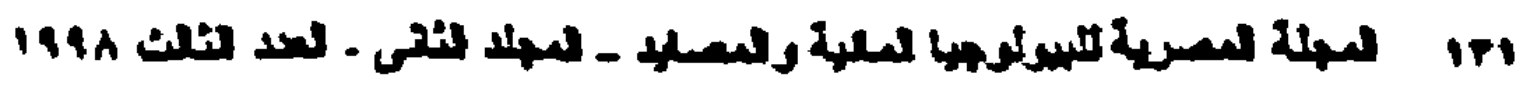

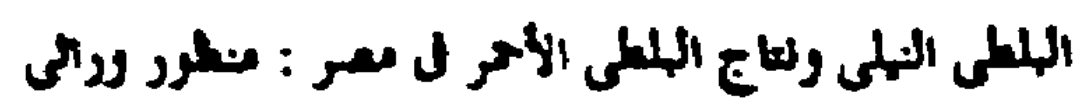

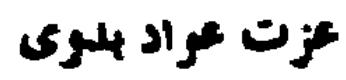

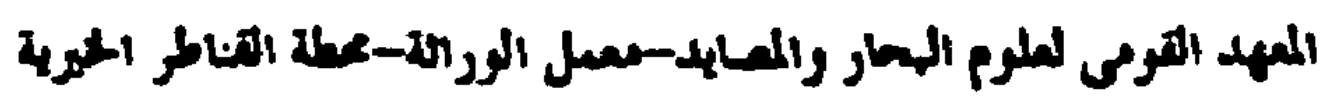

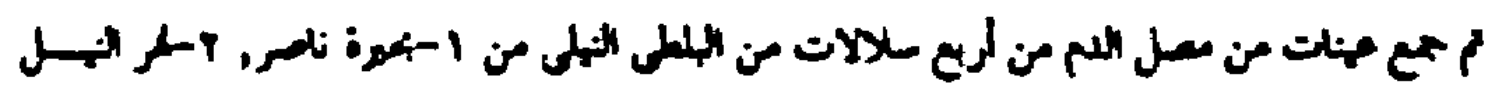

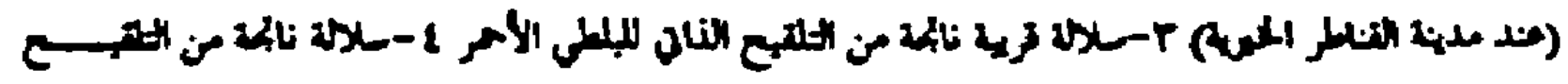

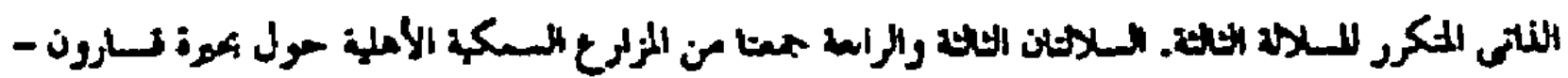

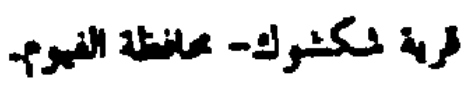

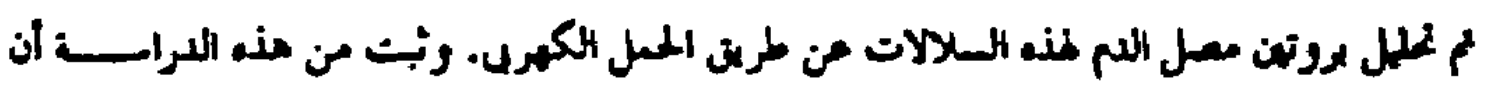

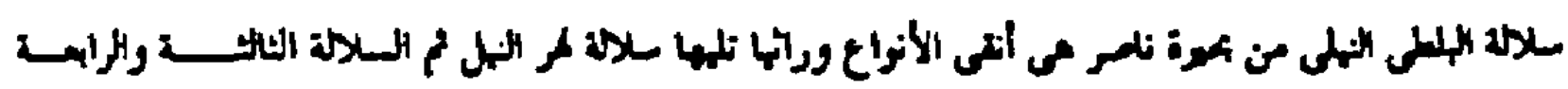

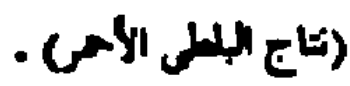

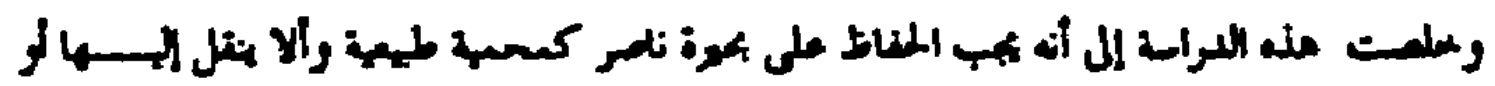

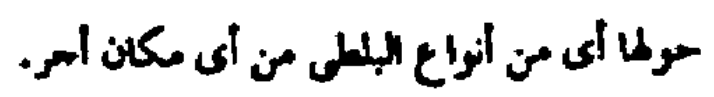

